\title{
6
}

\section{Donor initiatives to support infrastructure PPPs}

\section{Summarising the section}

- A number of donor facilities have been set up to support infrastructure PPPs in developing countries, including for project preparation, financing and funding.

- Project preparation facilities are mainly of three types: (i) facilities that provide advice to the government, such as the PPIAF and DevCo; (ii) facilities that play the role of a principal and take on the risks and costs of early stage project preparation, including InfraCo and InfraVentures; and (iii) facilities that provide funding for the different stages of the project development process, such as the Global Partnership for Output-Based Aid (GPOBA).

- Absence of long-term financing for infrastructure is one of the key constraints in developing countries; in response, donors have set up financing facilities such as the Emerging Africa Infrastructure Fund. Some IFIs also provide loan/debt products for infrastructure. These are usually commercially priced products, offered on a non- or limited-recourse basis.

- The two main types of donor guarantees for infrastructure financing are credit guarantees and political risk guarantees (PRGs).

- Donors also provide assistance for the funding of infrastructure projects. In particular, output-based aid donor programmes provide explicit performance-based capital subsidies to reduce the cost of connecting poorer households to networks.

As discussed in Section 5, developing countries face key constraints that have limited the quantity and quality of infrastructure PPPs. In response to these constraints, donor organisations have set up interventions to promote the successful implementation of PPPs. This section describes some of these, including:

- project preparation facilities;

- infrastructure financing facilities;

- guarantee facilities; and

- infrastructure funding facilities. 
These facilities can be accessed by Commonwealth governments to support infrastructure PPPs in their own countries. This section provides a general overview of the type of facilities and nature of support provided and Annex 4 gives a more detailed list of the individual facilities, including their sectoral and geographic focus.

\section{I. Project preparation facilities}

A range of donor facilities provide support across the stages of the project development cycle (see Section 4.2 for the cycle). At the highest level, these can be classified into three types of support:

Advisory: As the name suggests, the key role of advisory facilities is to provide advice to governments on project preparation for infrastructure PPPs. Such facilities recognise the constraint imposed by limited government capacity and hence aim to support the government through one or more stages of the project development process.

Principal: Unlike advisory support, some donor-funded facilities play the role of a principal, i.e. the facility takes on the risk and associated costs of early stage project development and develops the project for private sector investment. These facilities also help circumvent the problems caused by limited government capacity and relieve the constraint of limited PPP project development.

Funding for project preparation: A third type of support provided by some facilities is funding for the different stages of the project development cycle. Funding may be available for the public and/or the private sector.

Each of these types of support is discussed in further detail below. It should also be noted that some facilities provide both advisory and funding support.

\section{I.I. Advisory role}

Advisory project preparation facilities form the largest category of donor-funded project preparation facilities. Examples of these facilities include the following:

- The Public-private Infrastructure Advisory Facility ${ }^{1}$ focuses on providing advisory support for the development of an enabling environment for infrastructure PPPs (see Box 6.1 for an example of the type of support provided by the PPIAF).

- DevCo ${ }^{2}$ provides transactions advisory services to the government to support the implementation of a PPP transaction. (DevCo also comprises a non-core window on small-scale infrastructure programmes (SSIPs), which supports technical assistance and advisory services to encourage the development and expansion of smallscale infrastructure providers.)

- The African Capacity Building Foundation ${ }^{3}$ aims to build capacity in the core public sector through institutional strengthening and human capacity development.

- The Water and Sanitation Program (WSP) ${ }^{4}$ provides technical assistance support to governments for policy and institutional development in the water and 
sanitation sectors in sub-Saharan Africa. WSP also provides technical assistance support for investment and pilot approaches in the sector.

Thus, different advisory facilities focus on different stages of the project cycle, with some having a specific geographic or sectoral focus. Further examples are listed in Annex 4.

While some facilities provide grant-based support, others require a cost contribution (i.e. support is provided on the basis that the facility needs to recover part or all of its costs). In addition, some facilities may provide linked support (i.e. support from the facility requires a commitment to receive the facility's own products or services, either now or at a later stage of the project) and others may provide unlinked support, i.e. support is provided without the need to commit to any product or service from the facility itself (other than funding, the procurement rules mentioned above and/or ongoing engagement of the facility's task manager).

\section{Box 6.1. PPIAF advisory support for the development of a PPP framework in Malawi}

The Government of Malawi engaged the PPIAF to provide assistance in developing policies, laws and regulations for PPPs. This helped the government to:

1. Develop policies, laws and regulations that define the scope of authority within the various spheres of government to enter into PPP contracts;

2. Design an institutional set up to support and streamline PPP implementation, which will be guided by a set of institutional development principles.

In 2006, the team of consultants conducted extensive field research, interviews and reviews of existing reports in order to formulate a comprehensive government plan for the creation of a PPP policy and legal and institutional frameworks. At the end of this research and analysis period, the team prepared a draft Cabinet paper proposing specific actions that could be undertaken by government in order to establish such PPP frameworks. Following the completion of this assignment, the government plans to prepare detailed operating procedures and guidelines, illustrating the steps to be followed in the implementation of a PPP project, processes for approval and model transaction documents.

Source: PPIAF, www.ppiaf.org

\section{I.2. Role of a principal}

As mentioned above, there are a number of advisory facilities, each of which has its own core area of focus. However, more recently, the constraint of limited PPP project development, due to its high risks and costs, has been increasingly recognised; in response, donor-funded facilities have been designed to play the role of a principal and develop projects for private sector investment. InfraCo Africa ${ }^{5}$ and InfraCo Asia, funded by PIDG ${ }^{6}$ and InfraVentures, ${ }^{7}$ supported by the IFC, are important examples. These facilities are essentially structured as project development companies that take on the risks and associated costs of early stage project development, preparing projects for investment by the private sector. 


\subsubsection{Provision of funding support}

Some donor-funded facilities provide funding for project preparation to the public and/or private sector. Examples include the ACP-EU Energy Facility, ${ }^{8}$ which provides supplementary project preparation funds for energy sector projects and the PIDG Technical Assistance Facility (TAF), ${ }^{9}$ which provides funds for PIDG-supported projects. The funding may be grant based or a cost contribution, and may be linked or unlinked, as discussed above.

\subsection{Infrastructure financing facilities}

Lack of long-term finance for infrastructure projects is one of the key constraints faced by developing countries. In response, specialist donor-backed financing funds such as the Emerging Africa Infrastructure Fund (EAIF) have been set up (see Box 6.2).

\section{Box 6.2. Emerging Africa Infrastructure Fund ${ }^{10}$}

www.emergingafricafund.com

The EAIF is a US $\$ 498.5$ million debt fund established by the PIDG group of donors in 2002 to address the scarcity of long-term debt available to infrastructure projects in sub-Saharan Africa. It provides long-term (up to 15 years) US dollar- or Euro-denominated loans of US $\$ 10-36.5$ million, suitable for private sector projects, which are not typically available in local credit markets.

The EAIF lends on commercial terms, demonstrating the viability of long-term lending in the region. Despite operating on private sector principles, it attempts to boost its impact by focusing on projects that promote economic growth, poverty reduction and other social goals. Its remit covers support for greenfield projects, refurbishment, upgrade or expansion across telecom, transport, energy and certain other infrastructure sectors.

As at March 2009, the EAIF has provided support of US $\$ 443$ million to 22 projects, and nearly US $\$ 120$ million has already been repaid. An example of EAIF projects is the US $\$ 35$ million 15-year senior loan to the Bugoye Hydro Power Plant in Uganda in 2008. This $13 \mathrm{MW}$ project is expected to generate $82 \mathrm{GWh}$ each year. Its total costs are projected to be US $\$ 56$ million, US $\$ 16$ million of which is covered by grants and sponsor equity. The EAIF provided the loan to Tronder Power Ltd, the Special Purpose Vehicle (SPV) established to develop, construct and operate the project. Its principle investors are TrønderEnergi (a Norwegian hydro power expert) and Norfund (the Norwegian government's development fund). The Norwegian government is financing the $6 \mathrm{~km} 33 \mathrm{kV}$ line connecting the plant to the transmission network.

This project will have a region-wide impact through extending access, improving reliability and reducing the need for 'rolling blackouts'. The remote location of the station will also reduce losses from the transmission network. It is cheap and green power will be substitute for polluting and expensive diesel generation, especially as the government has cut subsidies for diesel generation and reduced the unit cost of electricity. The project will also promote skills transfer to local workers and the development of a domestic hydropower sector. Five hundred workers will be employed during the construction phase and ten on a permanent basis. 
In addition, a number of International Financial Institutions (IFIs) also provide loan/ debt products for infrastructure. These are commercially priced products offered by the IFIs to private sector borrowers, with an interest rate, tenor and repayment schedule that reflect the overall risks of the project. IFI loans are typically offered on a non- or limited- recourse basis (i.e. the lender does not have recourse to the project sponsor in the event of default), and require some upfront commitment fees. Most IFI loans are disbursed in foreign currency (US dollars or euros) as against a local currency loan, which is subject to exchange rate risks. Loans can be senior or subordinated - as the name suggests, senior loans have a higher priority over claims than subordinated debt (and are therefore less risky and bear a lower rate of return). Subordinated debt can be offered by the IFIs as a means of attracting senior debt from the private sector.

The main providers of long-term finance are Development Finance Institutions (DFIs), which are specialist financial institutions established primarily to provide finance to the private sector in developing countries, such as the IFC, the German investment and development company, DEG and the French Development Company, Proparco. ${ }^{11}$

Bilateral development banks, such as the Japan Bank for International Cooperation (JBIC) and German Development Bank (KfW), and multilateral development banks, such as the World Bank, International Bank for Reconstruction and Development (IBRD), IDA and European Investment Bank (EIB), may also provide financing for infrastructure PPP projects. However, most of their activities are focused on public infrastructure projects. Some multilateral development banks have established special windows for private sector lending.

\subsection{Guarantee facilities}

Closely linked to the above discussion on infrastructure financing facilities are donor facilities that provide guarantees for PPP infrastructure projects - and hence help facilitate both equity financing for the project, as well as debt financing of a suitable price and tenor. ${ }^{12}$

A guarantee facility assumes that banks and other providers of finance are willing to provide longer term finance if the key risks facing the lender or investor can be reduced or mitigated. These facilities provide financial products such as insurance or guarantees which protect lenders and investors in the event of default. This enhances the creditworthiness of the investment and helps to attract greater private sector investment. ${ }^{13}$

In return for providing a guarantee, the facility charges a fee or premium, which reflects the project's risks. Figure 6.1 presents a simple diagrammatic representation of how a guarantee works. 


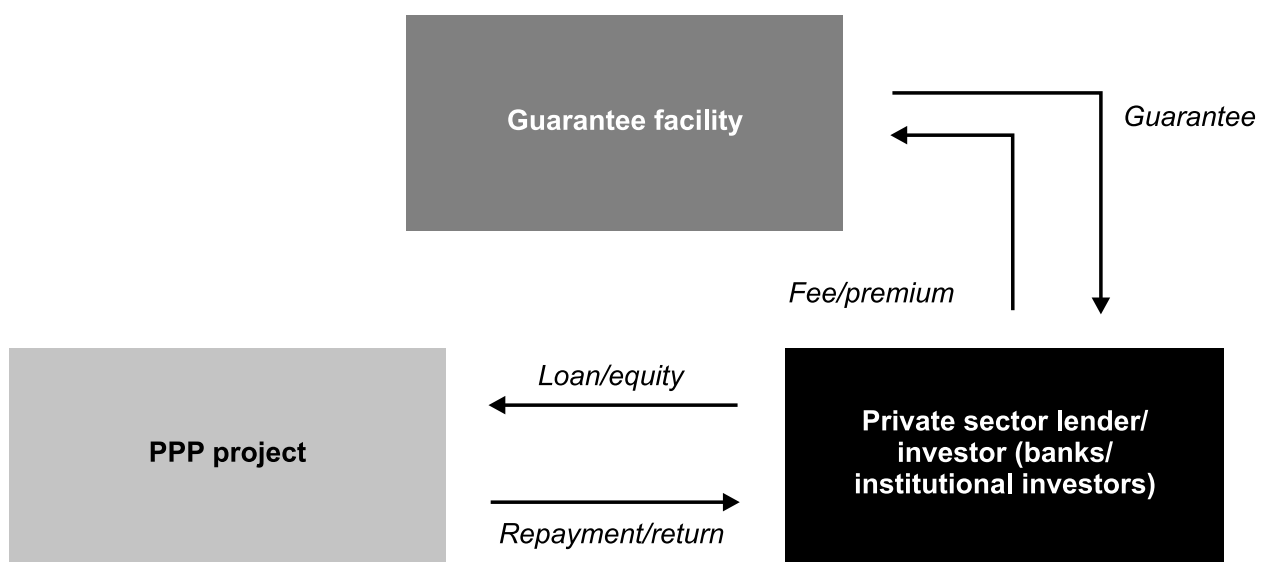

Figure 6.1. Typical structure of a guarantee

Donor guarantee facilities provide a range of different types of guarantee based on the type of finance provided, the underlying cause of the risk to be covered and the extent of coverage of potential losses. These are discussed in Table 6.1 below.

Table 6.1. Guarantees for infrastructure financing

\begin{tabular}{|c|c|c|}
\hline Criteria & Type & Description \\
\hline \multirow[t]{2}{*}{ Type of finance } & Equity financing & $\begin{array}{l}\text { Guarantees can be provided for equity or debt providers } \\
\text { of finance. }\end{array}$ \\
\hline & Debt financing & \\
\hline \multirow[t]{2}{*}{ Cause of risk } & Political risk & $\begin{array}{l}\text { Political risks include risks arising from war, civil distur- } \\
\text { bances, etc. and are usually the responsibility of the } \\
\text { government, as well as macroeconomic risks such as } \\
\text { exchange rate and interest rate volatility risks. }\end{array}$ \\
\hline & Commercial risk & $\begin{array}{l}\text { Commercial risks include contract performance risks, most } \\
\text { of which are directly under the control of the private } \\
\text { sector service provider, as well as construction and } \\
\text { market risks, where other factors and influences can } \\
\text { have an impact. }\end{array}$ \\
\hline \multirow[t]{2}{*}{$\begin{array}{l}\text { Extent of } \\
\text { coverage }\end{array}$} & Full & $\begin{array}{l}\text { Guarantees can cover part of the total financing or the } \\
\text { entire amount. }\end{array}$ \\
\hline & Partial & \\
\hline
\end{tabular}

Given the range of guarantees described above, the two main types of guarantees offered by donors' facilities are:

Credit guarantees: These cover debt service default, in the case of both political and commercial risks. Thus credit guarantees help improve the borrower's market access and terms of the debt. A number of multilateral development banks such as the 
African Development Bank (AfDB) and the Asian Development Bank (ADB) as well as DFIs such as the IFC provide credit guarantees (mostly Partial Credit Guarantees or PCGs).

Political risk guarantees or political risk insurance (PRI): These cover losses arising from political risks. PRGs usually cover the full amount of the debt, while PRIs can insure equity investors or lenders. Multilateral development banks such as the World Bank and ADB provide PRGs. There are also specialised agencies for PRI, such as the World Bank Multilateral Investment Guarantee Agency (MIGA).

In addition, export credit guarantees (ECGs) cover losses by exporters or lenders financing projects, tied to the export of goods and services; these may cover aspects of both political and commercial risks. ECGs are normally tied to the nationality of the exporters (and sometimes to that of the project sponsors or lenders), such as those provided by most of the European export credit agencies. However, untied guarantees are also available from a few bilateral agencies, such as the Japan Bank for International Cooperation.

More details on donor guarantee facilities are provided in Annex 4. For an example of a donor-funded guarantee facility support, see Box 6.3. Donor guarantees are often provided in conjunction with guarantees from private sector institutions, and play a 'crowding-in' role, as discussed in Box 6.4.

Box 6.3. GuarantCo support for Indian transport infrastructure finance

Most road freight in India is carried by small owner-operators. They are often unable to compete with larger operators as they are increasingly constrained by poor access to finance. Their small size makes it difficult to obtain credit from traditional sources, so they may have to resort to informal lenders to compete and meet new environmental regulations. GuarantCo, together with The Netherlands Development Finance Company (FMO), has decided to support specialist truck finance companies, whose existing supply of loans is overwhelmed by demand from drivers. GuarantCo's support comes in the form of a US $\$ 18.3$ million rupee guarantee for capital market securitisation of these truck loans.

Under the scheme, truck loans from specialist lenders are transferred to a special purpose company, which raises bonds from domestic investors. Adverse selection is minimised by specialist lenders retaining first loss risk defaults on their loans. GuarantCo and FMO provide a cash-backed second loss guarantee on the funds.

Securitising truck loans in this manner should have the effect of lowering the cost of finance for truck operators and extend access from a constrained position. It is estimated that the scheme will allow the extension of loans to an additional 64,000 trucks, all of which will have to meet more demanding environmental standards than the existing fleet.

Source: PIDG Annual Report 2008, www.pidg.org 


\section{Box 6.4. Guarantees provided by private financial entities}

In addition to the donor facilities that extend guarantees for infrastructure PPPs, a number of private financial institutions also provide risk-mitigating instruments. One such group of private financial entities are monoline insurers, such as MBIA, AMBAC and FSA. These are highly-rated companies that provide guarantees to structured debt issued by lower-rated sovereigns and corporations in exchange for insurance premiums. Such guarantees allow borrowers to issue higher-rated bonds, and may therefore attract a wider range of investors and result in significantly lower interest costs. A second group of private guarantors are the political risk insurers such as AIG, Chubb and Zurich, which work in a similar way to donors that provide PRIs.

One advantage to employing the services of private insurers is that, unlike many donor facilities, these entities are not limited by the borrower's nationality, which makes their products more accessible. That said, private insurers tend to have more stringent credit limits compared to donors, which may restrict the extent to which they are willing to work with higher-risk issuers.

Given their differences in risk appetite and coverage, the donors and private insurers can be mobilised in a complementary fashion to structure a more financially-attractive deal. One such example is the West African Gas Pipeline Project, which received US\$50 million PRG from IDA, US $\$ 75$ million PRI from MIGA and US\$125 million PRI from Steadfast Insurance Company.

Another project which benefited from a complementary approach is the Rutas del Pacifico toll road in Chile. An innovative 'co-guarantee mechanism' was developed for this project, whereby the Inter-American Development Bank (IDB) was the guarantor of record, not only for its account but also for the FSA which acted as the private co-guarantor. The IDB provided US $\$ 75$ million full-wrap financial guarantee, and the FSA co-guaranteed the remaining amount of about US $\$ 200$ million and benefited from the IDB's preferred creditor status.

\section{Key references}

Matsukawa, T and Odo H, Review of Risk Mitigation Instruments for Infrastructure Financing and Recent Trends and Developments, World Bank (2007).

http://www.ppiaf.org/documents/trends_and_policy/Riskmitigationinstruments.pdf

\subsection{Infrastructure funding facilities}

As against 'financing' of infrastructure, which refers to debt and equity for the construction and development of the infrastructure, 'funding' of an infrastructure project refers to payments for the use of the infrastructure service. As discussed in Section 5.1, a constraint faced in many developing countries is limited affordability for muchneeded infrastructure services, rendering the infrastructure project unsustainable.

Two types of subsidies may be provided:

1. Capital subsidies, or subsidies for the funding of the capital costs of the infrastructure. These are typically one-off, or sometimes multiple payment, to buy down the costs of capital provision. 
2. Operating subsidies, or funding for subsidising the use of the infrastructure services. These are often a series of payments that support operating costs and are used to fund public or merit goods where it is difficult or inappropriate to charge users the full cost of the service provision.

Donor support for infrastructure funding is provided indirectly through budgetary and other support - either grants or concessionary lending - by multilateral development banks, including the World Bank and the ADB.

In addition, other specific donor facilities targeted at infrastructure funding include output-based aid facilities such as the Global Partnership for Output-Based Aid ${ }^{14}$ and the PIDG TAF OBA window. ${ }^{15}$ Output-based aid is a strategy for using explicit performance-based subsidies to support the delivery of basic services where policy concerns justify public funding to complement or replace user fees. ${ }^{16}$ Thus, OBA facilities help fund economically desirable but commercially unbankable projects, where the price paid for the infrastructure service does not cover their cost or where risks are too high for the private sector to bear. OBA programmes usually focus on capital subsidies in order to reduce the cost of connecting poorer households to networks.

\section{Notes}

1. http://www.ppiaf.org/

2. http://www.ifc.org/ifcext/psa.nsf/content/Devco

3. http://www.acbf-pact.org/

4. http://www.wsp.org/

5. http://www.infracoafrica.com/

6. http://www.pidg.org/

7. http://www.ifc.org/

8. http://ec.europa.eu/europeaid/where/acp/regional-cooperation/energy/index_en.htm

9. http://www.pidg.org/organisationProfile.asp? $\mathrm{NavID}=40 \&$ step $=4 \&$ contentID $=9$

10. PIDG Annual Report 2008, http://www.pidg.org/uploads/public/documents/library/ PIDG/PIDG\%20Annual\%20Reports\%20and\%20Handbook/PIDG\%20Annual\%20 Report\%202008.pdf

11. Over time, the nature of DFIs has changed - mainly from fully publicly owned entities such as IFC to institutions such as FMO (Netherlands Development Finance Company), which is only partially government owned.

12. In the absence of guarantees, project risks can be so high that the commensurate interest rate or dividend would render the project unbankable.

13. Guarantee facilities also encourage local capital market development, as private lenders are encouraged to provide finance.

14. http://www.gpoba.org/

15. While GPOBA can provide funding for all developing countries (IDA or IDA blend countries), the TAF OBA window is restricted to PIDG-supported PPP projects. Both GPOBA and the TAF OBA window provide project preparation support in that they 
provide technical assistance for projects that are to be developed using the OBA approach, as well as providing direct funding of the OBA subsidy.

16. Affordability concerns for particular groups of users, positive externalities or the infeasibility of imposing direct user fees represent examples of the types of policy concerns that have motivated governments to use public funds to support the delivery of basic services.

\section{Key references}

PPIAF and ICA, Infrastructure Project Preparation Facilities: Africa User's Guide (2006).

http://www.ppiaf.org/documents/recent_publications/InfrastructureProjectPreparation FacilitiesUserGuideEnglish.pdf

Provides a description of the infrastructure project development process and the main activities involved, as well as providing details on available donor-funded facilities for project preparation support.

PPIAF and ICA, Donor Debt and Equity Financing for Infrastructure: User Guide Africa (2007). http://www.ppiaf.org/documents/other_publications/equityfinancingbookeng.pdf

Describes the main donor instruments and facilities available for financing infrastructure projects.

Matsukawa, T and Odo H, Review of Risk Mitigation Instruments for Infrastructure Financing and Recent Trends and Developments, World Bank (2007).

http://www.ppiaf.org/documents/trends_and_policy/Riskmitigationinstruments.pdf

Reviews guarantees and insurance, providing a broad overview with further links for practitioners. 